\title{
Spatial and temporal patterns of harvesting of the Vulnerable pig-nosed turtle Carettochelys insculpta in the Kikori region, Papua New Guinea
}

\author{
Carla C. Eisemberg, Mark Rose, Benedict Yaru and Arthur Georges
}

\begin{abstract}
Management of wildlife use by communities living a partially traditional lifestyle is usually more successful when the interactions between those communities and the environment are well understood. We mapped the harvest areas for the Vulnerable pig-nosed turtle Carettochelys insculpta for six language-groups in the Kikori region of Papua New Guinea and compared harvest parameters between different areas and language-groups and, when possible, between 1980-1982 and 2007-2009. Spatially, the main influence on harvest method was a tribe's location relative to the turtle's distribution. No small juveniles $(<20 \mathrm{~cm}$ straight-line carapace length) were found outside the Kikori delta, which is probably the species' feeding grounds. In contrast, nesting females were captured only in upstream and coastal sandbank areas. Temporally there were distinct differences in harvesting parameters between tribes, which may be explained by differential employment opportunities. To halt the decline of pig-nosed turtles in the Kikori region we recommend the establishment of beach and feedingground protection initiatives, together with monitoring of the turtle population and harvest. Concomitantly, trips specifically targeted at harvesting the turtles, which account for $81 \%$ of the animals captured, need to be restricted. These initiatives should include all six language-groups and take into account their specific harvesting patterns.
\end{abstract}

Keywords Consumption trend, fishing technology, harvest methods, language-groups, pig-nosed turtle, Papua New Guinea, sex ratio, wildlife management

\section{Introduction}

Tild-meat consumption in developing countries is a significant issue in conservation (Barnes, 2002; Sodhi et al., 2004; Nasi et al., 2008). Modern hunting

\footnotetext{
Carla C. EISEMberg ${ }^{*}$ (Corresponding author), Benedict Yaru† and Arthur GeORGES Institute for Applied Ecology, University of Canberra, ACT 2601, Australia. E-mail eisemberg@aerg.canberra.edu.au

MARK Rose Fauna \& Flora International, Cambridge, UK

*Also at: Research Institute for the Environment and Livelihoods, Charles Darwin University, Australia

$\dagger$ Also at: EcoCare Engineering Ltd, Port Moresby, Papua New Guinea

Received 7 October 2013. Revision requested 25 November 2013.

Accepted 20 December 2013. First published online 14 July 2014.
}

technologies, loss of traditional hunting controls, increases in human populations, commercialization of biological resources, and greater access to these resources as a result of road construction and forest fragmentation are among the main factors that have contributed to increased harvesting of wild meat (Bennett \& Robinson, 2000). Changing social and economic factors can also influence whether or not a resource will be exploited, where it will be exploited and to what extent (Campbell, 2002; Mascia et al., 2003). This in turn will influence the future trajectory of wildlife species and may lead to local extirpation (Henderson, 1974; Honegger, 1981; Carlton et al., 1999).

Achieving positive outcomes from conservation and sustainable-use programmes in culturally diverse countries presents complex challenges (Nazarea et al., 1998). Papua New Guinea is such a country, with $>500$ languages (Foley, 1986), and $97 \%$ of its land privately owned (Lynch \& Marat, 1993). The land is held by kinship groups or individuals according to the customary system of each tribe. This cultural diversity brings added complexity. Any resource planning and control is constrained and needs to be introduced with sensitivity (Stubbs, 1989).

The Kikori region in the Gulf Province of Papua New Guinea can be considered a microcosm of the complex issues that arise when trying to achieve conservation objectives. Many tribes coexist in the region and differ in language, use of natural resources and response to cultural changes. Interactions between Kikori indigenous communities and Europeans began in the late 19th century (David, 2008) and since then the region has become the country's first major site for oil development (Price et al., 1994; Gilberthorpe, 2009). New developments include the construction of a gas pipeline (Papua New Guinea's largest industrial enterprise) and roads connecting Kikori to other major towns for the first time (ACIL-Tasman, 2009). Reversing the decline of the pig-nosed turtle Carettochelys insculpta in this context is an example of the challenges faced by wildlife management (Eisemberg et al., 2011).

Widely distributed in southern New Guinea, C. insculpta is of conservation concern because it is the sole survivor of a once widespread family of turtles, has a restricted global distribution and is subjected to intense harvest pressure through much of its range (Rose et al., 1982; Georges et al., 2008a,b). In the Gulf of Papua almost 90\% of C. insculpta eggs are harvested during the nesting season (SeptemberMarch; Pauza, 2003; Georges et al., 2008a). The introduction 
of new technologies, such as fishing line, net, snorkel masks and outboard motors, is cited as one of the main causes for the increase in harvest pressure on the pig-nosed turtle (Rose et al., 1982) and may have contributed to an estimated population decline of $57 \%$ since 1982 (Eisemberg et al., 2011). The species is categorized as Vulnerable on the IUCN Red List (Asian Turtle Trade Working Group, 2000).

Formulation of a management and conservation plan for the species requires an understanding of the diverse ways in which humans interact with turtles, especially if these interactions differ among the ethnic groups in the region. It is also important to identify how each group has responded to the introduction of new technologies. Here we address this critical gap in knowledge required to engage the local community in meeting the challenges of changing patterns of wildlife use. We report on the areas used for turtle harvesting by each group (based on language) in the Kikori delta and the relative number of turtles harvested by each group. We describe associations between harvest parameters, turtle size and sex ratio within different areas and language-group aggregations. We also compare tribes' current harvesting characteristics with those reported during 1981-1982. Finally, we use this information to identify options for the Kikori communities to consider, to introduce more sustainable harvest practices.

\section{Study area}

The Kikori drainage extends from the alpine grasslands of Doma Peaks, in the Southern Highlands Province of Papua New Guinea, to the extensive mangrove wetlands of the Gulf Province (Fig. 1). The meandering river system is confined within its limestone bed. The delta is an alluvial plain at $<40 \mathrm{~m}$ altitude, with a distributary system of river channels, formed by the deposition of layers of soil, principally soft silts and clays, over the underlying limestone plain. The coast comprises the delta islands exposed to the Gulf of Papua. Coastal beaches, sand bars and sand islands are created by wind and wave action (Enesar Consulting, 2005).

There are 51 villages and fishing camps in this area. They are divided into six distinct ethnic groups with different languages and fishing areas (Fig. 1). We recognize the following language-groups and dialects, confirmed by reference to Ethnologue (Gordon \& Grimes, 2005), the Pacific Language Mapping Project (Blundell, 2006) and other reports (Wurm \& Hattori, 1981): Rumu, Kasere (Ikobe), Kerewo (Goarebari), Urama (Kiwai) and Porome (which can be subdivided into Kibiri and Porome). New settlements and the main town of Kikori comprise a mixture of groups that primarily speak the common language Motu. Those locations were omitted from the analysis. For our spatial analysis we aggregated language-groups on the basis of their location as follows: Rumu-Kasere (riverine villages),
Porome-Kibiri (delta villages) and Kerewo-Urama (delta and coastal villages). Kasere villages $(n=1)$ and Rumu villages $(n=5)$ are on the river, upstream of the delta; Kibiri $(\mathrm{n}=2)$ and Porome villages $(\mathrm{n}=2)$ are all in the delta; Kerewo villages $(n=7)$ occupy both delta and coastal areas; the single Urama village is on the coast (Fig. 1).

\section{Methods}

\section{Spatial patterns in harvest (2007-2009)}

To investigate spatial patterns in the turtle harvest we collected data from 19 villages and associated fishing camps across the study site during the 2007-2008 and 2008-2009 nesting seasons (September-March). Villages were visited by CCE at least twice in each nesting season. Volunteers were recruited in each village to record information on harvesting and to keep turtle shells after consumption. Data from these volunteers were validated during village meetings, by the hunter or a participant in the harvest. Harvest of pig-nosed turtle for local consumption and sale is a legal activity in this area and there is no reason for locals to underreport their catches.

When shells or live turtles were available we measured the maximum straight-line carapace length (SCL). We sought information on the location and date of capture, capture method (fishing line, net, spear, by hand while diving with snorkel masks, or capture of female nesting on the sandbank), sex and maturity status (female, male, juvenile), objective of the hunting trip (whether it was specifically targeted at turtles or not) and mode of transport used by hunters (canoe, motorboat or walking). Where possible the destiny of the animal after capture was also recorded (sold in the main markets or not). The two main markets are Kikori and Sirebi markets (Fig. 1). As captures were skewed towards females nesting in the coastal and riverine areas we performed a second analysis, using only animals captured by fishing line and net, to assess a possible difference in sex ratio between areas.

The hunting area used by each language-group (Fig. 1) was determined from the recorded locations of harvest. Turtle consumption was calculated as the number of turtles caught divided by the number of inhabitants in each language-group surveyed (PNG Census, 2000) and expressed as the number of turtles per 100 residents. We also calculated the mean capture rate for the nesting season.

\section{Temporal patterns in harvest (1980-1982 and} 2007-2009)

Data from 1980-1982 were collected by MR and three trained assistants at the Kikori market and in villages. One of these assistants became a volunteer recorder for the 


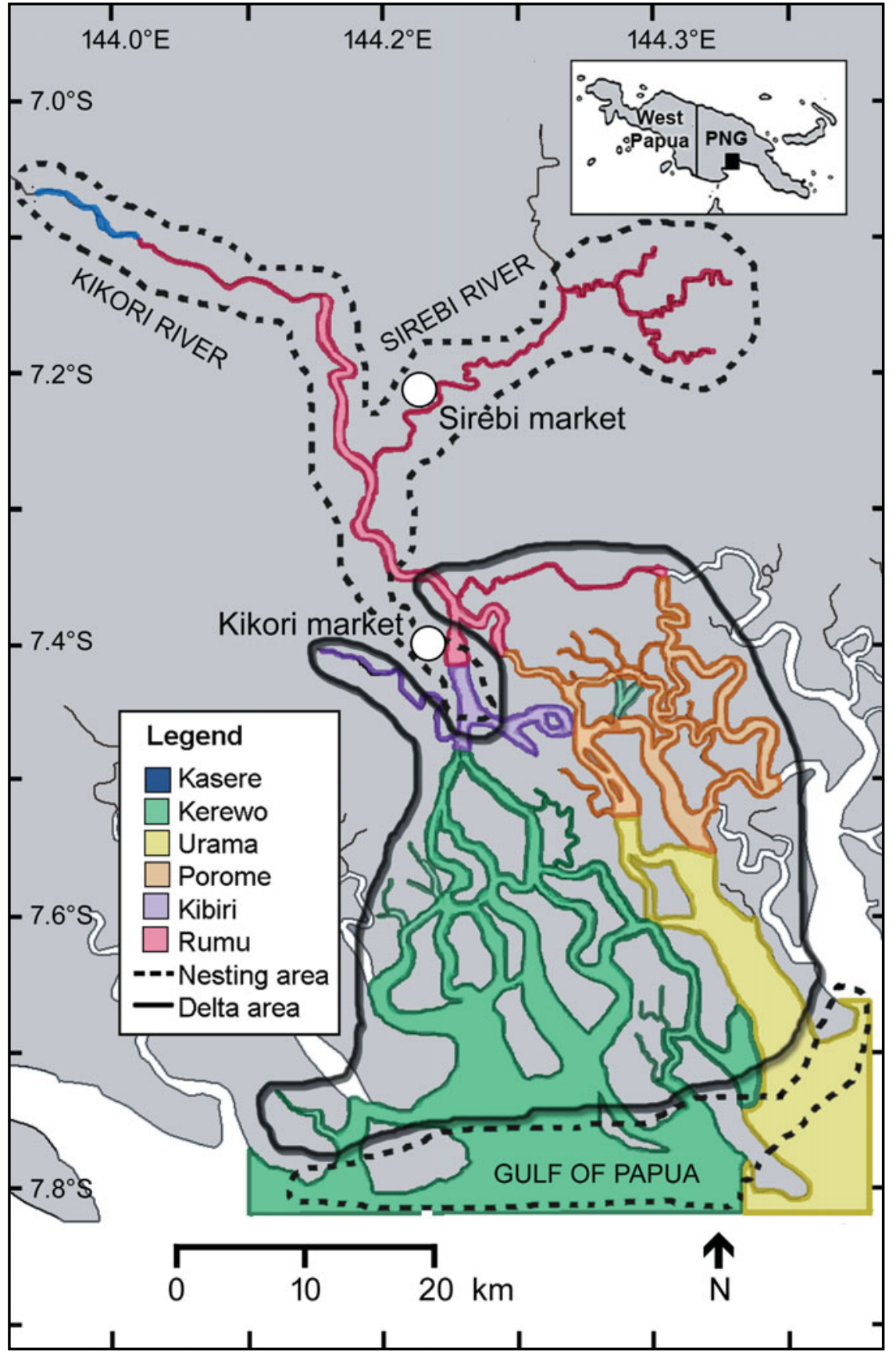

FIg. 1 The Kikori region of Papua New Guinea, with the fishing areas of the tribal groups. The rectangle on the inset shows the location of the main map in Papua New Guinea.
2007-2009 period and helped to standardize the methodology. Similar questionnaires and data validation systems were used during both periods. As was the case during 2007-2009 there was no reason for hunters to underreport their catches during 1980-1982. Only villages visited during both periods were used in the temporal analysis. Six Kerewo villages (Aedio, Apeowa, Babaguna, Dopima, Goare, Samoa) and four Rumu villages (Irimuku, Kopi, Ogomabu, Waira) were surveyed during both 1980-1982 and 2007-2009. There were no data available to compare Porome-Kibiri tribes between the two periods.

Only turtles captured during the same period of the year during 2007-2009 (nesting periods: September 1980-March
1981 and September 1981-March 1982) were considered in the analysis. It was possible to compare the tribe responsible for the capture, the harvest method and the destiny of the animal after capture (the Kikori market was the only main market available during 1980-1982) between the two periods. Other parameters recorded during 2007-2009 (sex/maturity status, objective of the trip, and transport) were not recorded during 1980-1982.

\section{Statistical analysis}

We tested differences in hunting parameters among areas, tribes and periods, using Pearson $\chi^{2}$ and 
TABLE 1 Language-group, population, number of villages, number of pig-nosed turtles Carettochelys insculpta caught per 100 inhabitants, and mean nesting-season capture rate during September 2007-March 2009 in the Kikori region, Papua New Guinea (Fig. 1). Each languagegroup represents one ethnic group. Census data were provided by WWF-Papua New Guinea (PNG Census, 200o).

\begin{tabular}{|c|c|c|c|c|c|c|c|}
\hline \multirow{2}{*}{$\begin{array}{l}\text { Language- } \\
\text { group }\end{array}$} & \multirow[b]{2}{*}{ Population } & \multicolumn{4}{|c|}{ Number of villages } & \multirow{2}{*}{$\begin{array}{l}\text { No. of turtles caught } \\
\text { per } 100 \text { inhabitants }\end{array}$} & \multirow{2}{*}{$\begin{array}{l}\text { Mean nesting-season } \\
\text { capture rate }\end{array}$} \\
\hline & & Coast & Delta & River & Total & & \\
\hline Kasere & 223 & 0 & 0 & 2 & 2 & 2.69 & 3 \\
\hline Kerewo & 1,053 & 4 & 3 & 0 & 7 & 7.41 & 39 \\
\hline Kibiri & 146 & 0 & 2 & 0 & 2 & 6.16 & 4.5 \\
\hline Porome & 908 & 0 & 2 & 0 & 2 & 1.21 & 5.5 \\
\hline Rumu & 997 & 0 & 0 & 5 & 5 & 3.71 & 18.5 \\
\hline Urama & 332 & 1 & 0 & 0 & 1 & 1.20 & 2 \\
\hline Total & 3,659 & 5 & 7 & 7 & 19 & 3.96 & 72.5 \\
\hline
\end{tabular}

Cramer's V coefficient. In $\chi^{2}$ tests counts of turtles were the independent entities satisfying the underlying multinomial assumptions. An ANOVA (analysis of variance) was carried out to test the differences in size among individuals from the coast, delta and river. It was preceded by an analysis of residuals to test the assumptions of normality of variances. A Levene's test was used to assess the homogeneity of variances. A Welch ANOVA was performed for unequal variances. Multiple comparisons following significant results in the ANOVA were made using the Tukey-Kramer HSD (honestly significant difference) procedure. Statistical tests were performed using SPSS $v .17$ (SPSS Inc., Chicago, USA) and JMP v. 7 (SAS, Cary, USA).

\section{Results}

\section{Spatial patterns in harvest (2007-2009)}

We recorded 145 pig-nosed turtles harvested from 19 villages during the 2007-2008 and 2008-2009 nesting seasons. Rumu and Kerewo tribes (occupying 12 of the 19 villages included in the study) together were responsible for $79.3 \%$ of the total harvest during the 2007-2008 and 2008-2009 nesting seasons. However, Kibiri and Kerewo tribes consumed the highest proportion of turtles per inhabitant (Table 1). In general, tribes harvested turtles according to their location, with Kerewo-Urama having a coastal pattern, Porome-Kibiri a delta pattern and Rumu-Kasere a river pattern (Table 2; Figs 1 \& 2).

One turtle was captured by spear and five by diving with mask. These six were not included in the $\chi^{2}$ analysis to test differences among areas and tribes. Females accounted for $74.4 \%$ of captures $(n=133)$, with $65.7 \%$ of those $(n=99)$ captured when nesting. The proportion of females, males and juveniles harvested differed significantly between regions (Table 2; Figs 2 \& 3). Juveniles were caught almost exclusively in the delta, and most of the individuals captured on the coast were females. This is partly a result of the different hunting methods used. Capture of nesting female turtles was the most common hunting method in coastal and riverine areas, whereas in the delta the most common method of capturing turtles was by fishing line (Table 2; Fig. 2). However, even when only animals caught using fishing line and net were considered the proportion of females, males and juveniles was still significantly different between regions (coast: $70.6 \%$ females, $0 \%$ juveniles, $29.4 \%$ males, $\mathrm{n}=17$; delta: $40 \%$ females, $48.6 \%$ juveniles, $11.4 \%$ males, $\mathrm{n}=35$; river: $58.3 \%$ females, $25 \%$ juveniles, 16.7\% males, $\mathrm{n}=12$; Table 2).

Levene's test indicated unequal variances in turtle size between areas, with a greater variance of size in the delta $(F=14.759$, df $=2,71, \quad \mathrm{P}<0.001)$. A greater frequency of smaller individuals in the delta was reflected in the smaller mean size of turtles from the delta (35.37 \pm SE $2.19 \mathrm{~cm}$ SCL, $\mathrm{n}=43)$ compared to those from the coast $(48.18 \pm \mathrm{SE} 0.88 \mathrm{~cm}$ SCL, $\mathrm{n}=18)$ and river (41.13 \pm SE $2.85 \mathrm{~cm}$ SCL, $\mathrm{n}=13$; Welch ANOVA followed by Tukey-Kramer HSD; $F=15.998$, df = 2,29.05, $\mathrm{P}<0.001$; Fig. 4). No small juveniles $(<20 \mathrm{~cm}$ SCL) were collected outside the delta. The minimum size was $43.2 \mathrm{~cm}$ at the coast, $17.5 \mathrm{~cm}$ in the river and $6.9 \mathrm{~cm}$ in the delta.

Most captured animals were not sold in markets (81.2\%, $\mathrm{n}=138)$. Riverine villages had the highest proportion of animals sold in the market $(35.9 \%)$ and delta villages the lowest (4.5\%; Table 2; Fig. 2). Turtles not sold in the market were consumed or sold locally. In total, $20.4 \%$ of the turtles were captured accidentally. In contrast, $95.8 \%$ of coastal turtles, $50 \%$ of delta turtles and $75.8 \%$ of river turtles were captured during targeted harvesting trips (Table 2; Fig. 2). There was a significant difference in the proportion of females $(93.7 \%, \mathrm{n}=79)$, juveniles $(0 \%, \mathrm{n}=8)$ and males $(50 \%, \mathrm{n}=10)$ captured during such trips (Table 2). Only one capture while nesting $(2 \%, \mathrm{n}=57)$ and 14 captures using fishing line $(37 \%, \mathrm{n}=38)$ occurred during trips that were not targeted at harvesting turtles.

It was possible to identify the means of transport for 79 of the captured turtles. Most turtles were captured by hunters using traditional means of transport, such as canoes $(78.5 \%$, $\mathrm{n}=69)$ and walking $(10.1 \%, \mathrm{n}=8)$. Only $11.4 \%(\mathrm{n}=9)$ of captures involved boats with motors (up to $50 \mathrm{hp}$ ). Hunters 
TABle 2 Pearson $\chi^{2}$ and corresponding P-values for hunting parameters of pig-nosed turtle C. insculpta in the Kikori region of Papua New Guinea (Fig. 1) among different areas and tribes during two periods (1980-1982 and 2007-2009 nesting seasons), with Cramer's V coefficient $(\varphi c)$, number of turtles (n), and degrees of freedom (df). Hunting parameters tested were sex of the captured turtle (female, male or juvenile), initial objective of the hunting trip (specifically to capture turtles or not), mode of transport used by hunters (canoe, motor boat or walking), capture method (fishing line or capture of female nesting on the sandbank), and destiny of the animal after capture (sold in the main markets or not).

\begin{tabular}{lrlrrr}
\hline Parameters & $\chi^{2}$ & $\mathrm{P}$ & $\varphi \mathrm{c}$ & $\mathrm{n}$ & $\mathrm{df}$ \\
\hline Area & & & & & \\
$\quad$ Sex $\left(\right.$ Total $\left.^{1}\right)$ & 44.93 & $<\mathbf{0 . 0 0 0 1}$ & 0.41 & 133 & 4 \\
Sex $\left({\mathrm{F} \& \mathrm{~N}^{2}}^{\text {}}\right)$ & 13.19 & $<\mathbf{0 . 0 5}$ & 0.32 & 64 & 4 \\
Objective & 19.97 & $<\mathbf{0 . 0 0 0 1}$ & 0.44 & 103 & 2 \\
Transport & 9.51 & $<\mathbf{0 . 0 1}$ & 0.35 & 79 & 2 \\
Method & 60.01 & $<\mathbf{0 . 0 0 0 1}$ & 0.47 & 136 & 4 \\
Destiny & 13.32 & $<\mathbf{0 . 0 0 1}$ & 0.31 & 138 & 2 \\
Tribe & & & & & \\
Sex (Total & & & & \\
Objective & 23.682 & $<\mathbf{0 . 0 0 0 1}$ & 0.30 & 133 & 4 \\
Transport & 24.03 & $<\mathbf{0 . 0 0 0 1}$ & 0.48 & 103 & 2 \\
Method & 9.96 & $<\mathbf{0 . 0 1}$ & 0.36 & 79 & 2 \\
Destiny & 10.48 & $<\mathbf{0 . 0 0 0 1}$ & 0.35 & 136 & 4 \\
Sex & & & 0.28 & 138 & 2 \\
Objective & 49.47 & $<\mathbf{0 . 0 0 0 1}$ & 0.71 & 97 & 2 \\
Period & & & & & \\
Area & 34.52 & $<\mathbf{0 . 0 0 0 1}$ & 0.44 & 175 & 2 \\
Tribe & 27.37 & $<\mathbf{0 . 0 0 0 1}$ & 0.40 & 175 & 1 \\
Method & & & & & \\
$\quad$ Kerewo & 2.00 & 0.20 & 0.17 & 70 & 1 \\
$\quad$ Rumu & 5.03 & $<\mathbf{0 . 0 5}$ & 0.23 & 96 & 1 \\
$\quad$ Total & 16.13 & $<\mathbf{0 . 0 0 1}$ & 0.31 & 166 & 1 \\
Destiny & & & & & \\
$\quad$ Kerewo & 18.64 & $<\mathbf{0 . 0 0 1}$ & 0.50 & 75 & 1 \\
$\quad$ Rumu & 990.07 & 0.80 & 0.03 & 99 & 1 \\
$\quad$ Total & 8.80 & $<\mathbf{0 . 0 1}$ & 0.23 & 174 & 1 \\
\hline
\end{tabular}

${ }^{1}$ All capture methods

${ }^{2}$ Fishing line and net

from riverine villages used motor boats most frequently. Hunters from delta villages captured only one animal while using a motor boat and there was no record of hunters from coastal villages using motor boats to capture turtles (Table 2; Fig. 2).

Temporal patterns in harvest (1980-1982 and 2007-2009)

During 1980-1982 and 2007-2009 a total of 98 and 77 turtles were recorded, respectively, from villages surveyed in both periods. There was a significant change in the proportion of turtles captured in different areas from 1980-1982 to $2007-2009$, with a $42 \%$ decrease in the proportion of
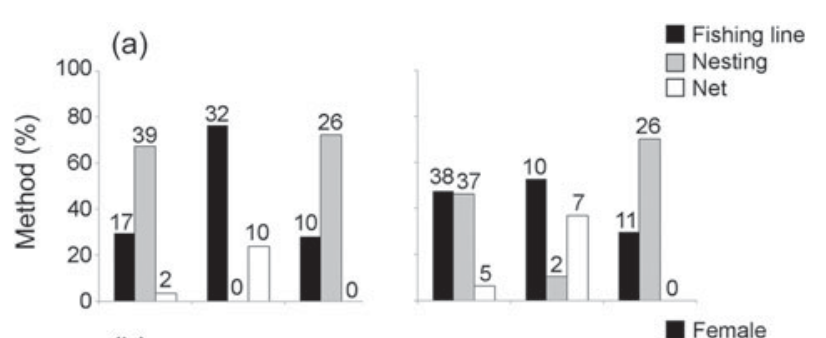

(b)
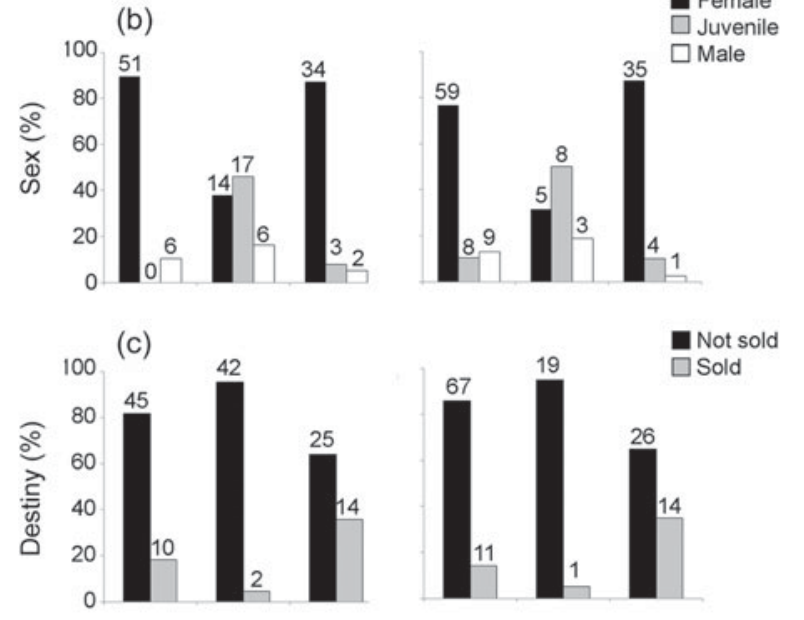

(d)
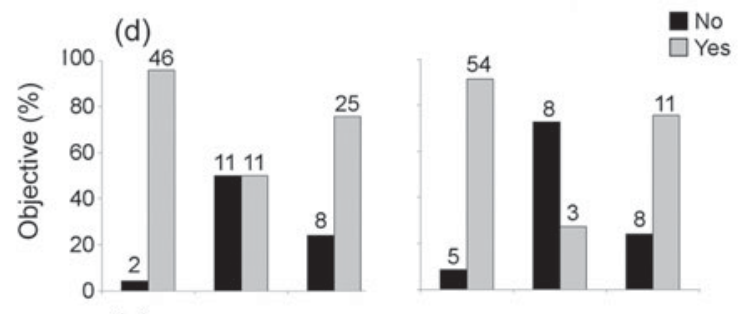

(e)

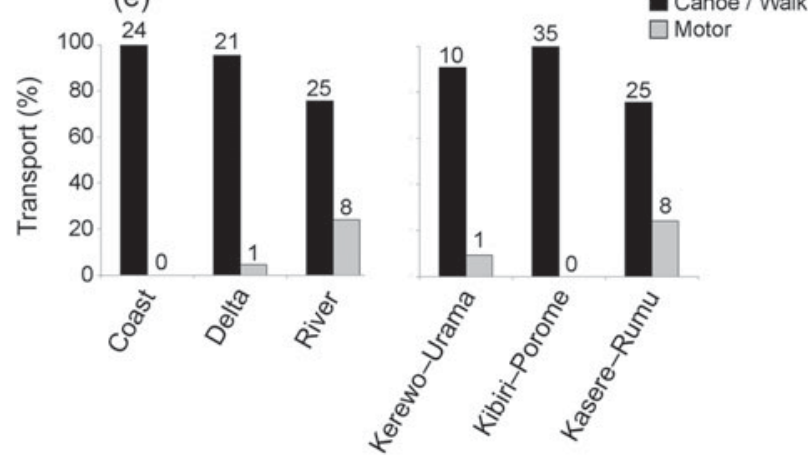

FIG. 2 Percentage of pig-nosed turtles Carettochelys insculpta harvested by the tribal groups Kerewo-Urama, Porome-Kibiri and Rumu-Kasere in coastal, delta and river areas of the Kikori region (Fig. 1), according to (a) method of capture (fishing line, nesting, net), (b) sex/maturity status (female, juvenile, male),

(c) destiny after capture (sold in the markets, not sold), (d) whether the species was specifically targeted by hunters (yes, no), and (e) hunters' mode of transport (canoe/walking, by boat with motor up to $50 \mathrm{hp}$ ). Numbers above the bars represent numbers of turtles.

turtles captured in riverine areas, and 26.4 and $15.7 \%$ increases in coastal and delta areas, respectively. This change is attributable to an increase in the proportion of turtles captured by the Kerewo tribe, from $25.5 \%$ during 1980-1982 


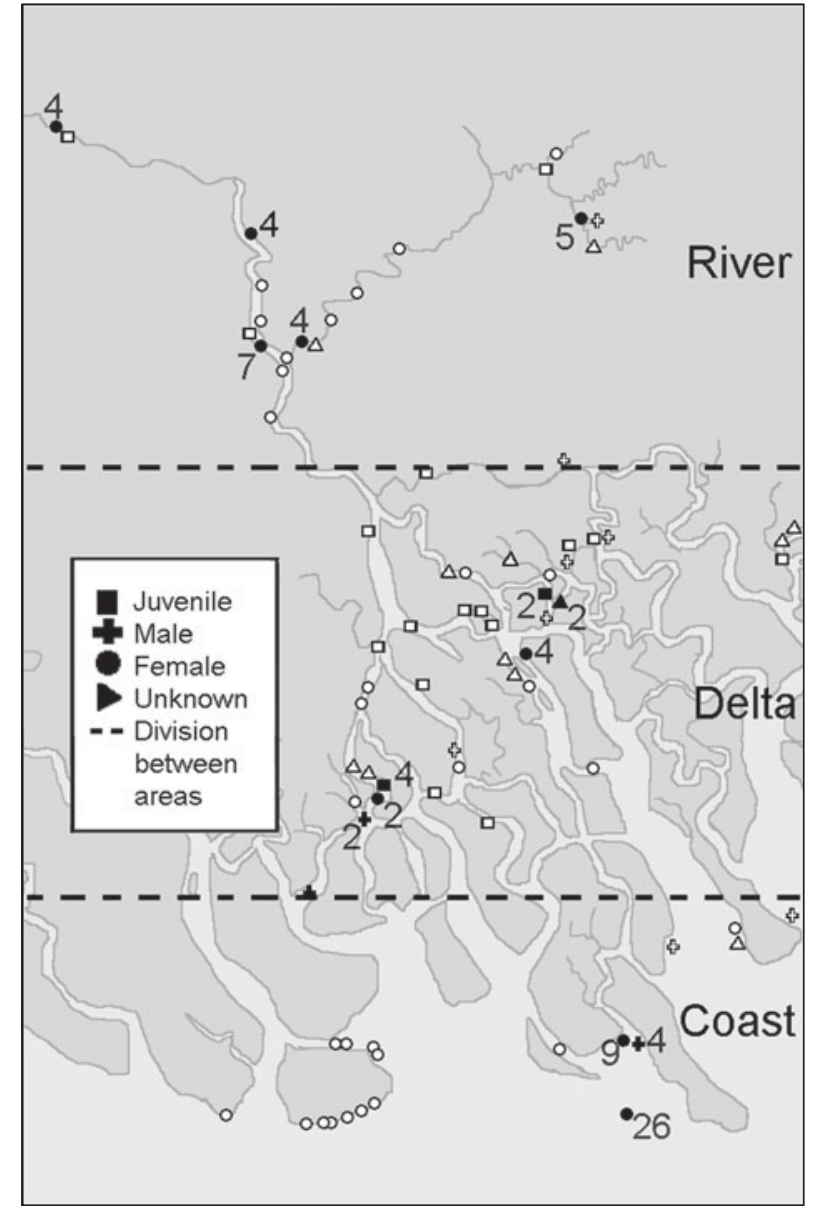

FIG. 3 Locations where female, male and juvenile pig-nosed turtles were harvested in the Kikori region (Fig. 1) during the 2007-2008 and 2008-2009 nesting seasons $(n=145)$. Animals of unknown sex were not included in the analysis. Unfilled symbols indicate a single capture and symbols filled in black indicate that more than one female/male/juvenile were captured (numbers indicate the number of individuals harvested).

to $64.9 \%$ during 2007-2009 (Table 2; Fig. 5). This tribe has villages in both coastal and delta areas.

The people of Kerewo used nets to capture three turtles, and a spear to capture one turtle, during 2007-2009. In the same period the people of Rumu captured three turtles by diving with masks. These three methods of capture were not mentioned during 1980-1982; given the low frequency of captures using these methods during 2007-2009, turtles captured by nets, spear or diving were not included in the $\chi^{2}$ analysis to test differences between periods. Hunting method did not differ significantly between 1980-1982 and 2007-2009 for the Kerewo, who made $75 \%$ of their captures by fishing line. There was a $19.4 \%$ increase in the use of fishing line by the Rumu (Table 2; Fig. 6) and overall there was a $31.4 \%$ increase in the use of fishing line to capture turtles and an $18.3 \%$ decrease in the number of turtles captured while nesting (Table 2; Fig. 6). There was a $46 \%$ decrease in the number of turtles sold in the markets by

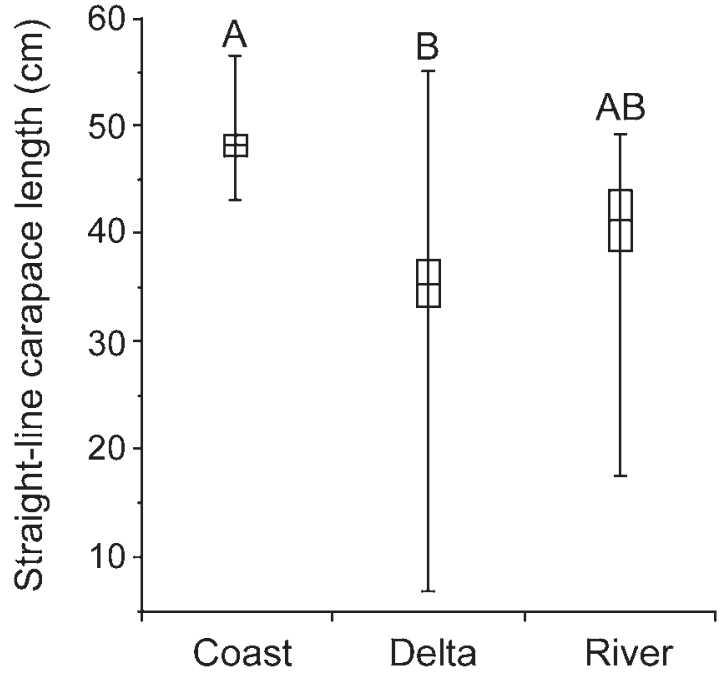

FIG. 4 Variation in straight-line carapace length (SCL) of pignosed turtles across areas of the Kikori region (Fig. 1). Means are given with 95\% confidence limits (boxes) and ranges (vertical bars). Levels not connected by same letter are significantly different, according to Tukey-Kramer HSD.

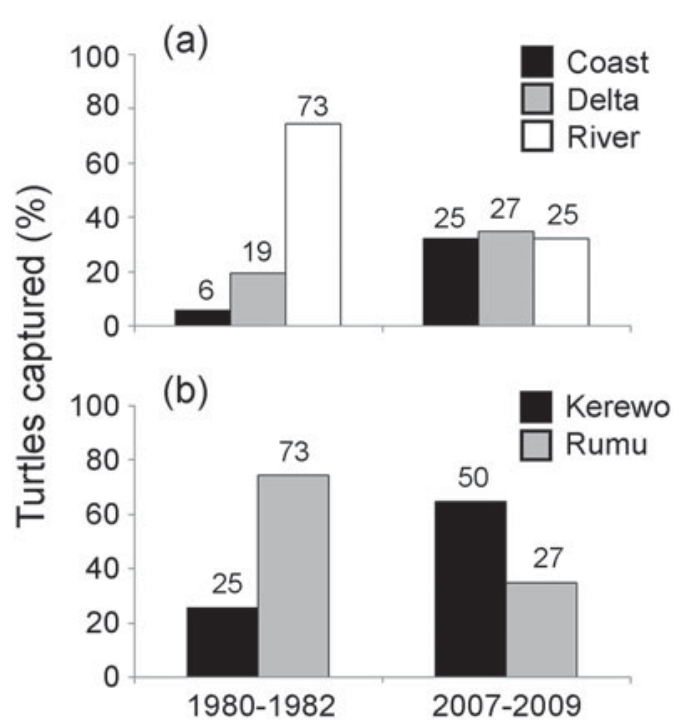

FIG. 5 Percentage of pig-nosed turtles captured in (a) the coast, delta and river and (b) by the Kerewo and Rumu tribes of the Kikori region (Fig. 1) during the nesting seasons of 1980-1982 and 2007-2009. Numbers above the bars represent numbers of turtles.

Kerewo and no significant change in the number sold by Rumu (Table 2; Fig. 6).

\section{Discussion}

Spatial patterns in harvest (2007-2009)

Interactions between humans and turtles varied across the ethnic groups that inhabit specific parts of the Kikori region. 

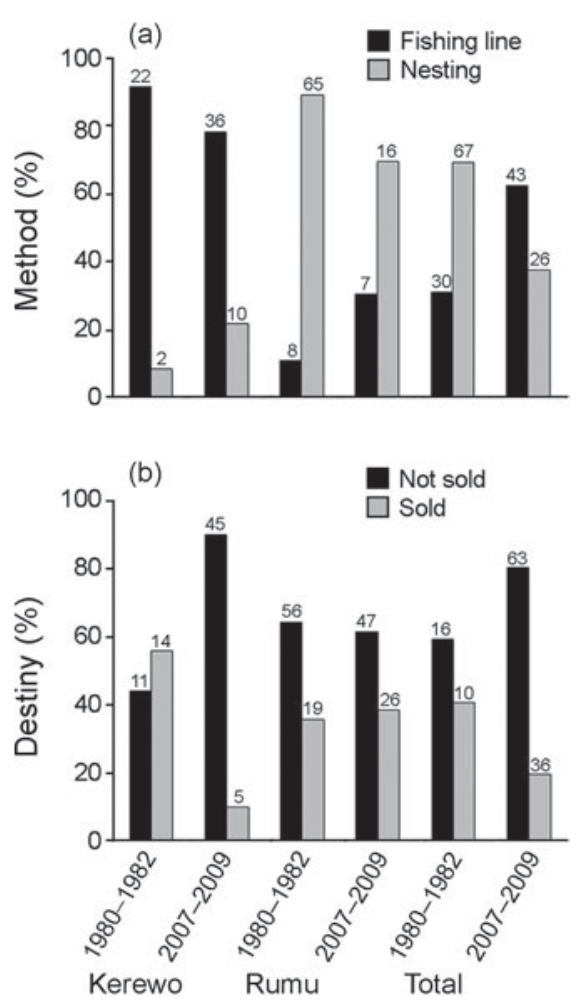

FIG. 6 Percentage of pig-nosed turtles harvested by the Kerewo and Rumu tribes during the nesting seasons of 1980-1982 and 2007-2009, according to (a) capture methods (fishing line or nesting) and (b) destiny (sold to the main markets or not). Numbers above the bars represent numbers of turtles.

We found differences in the use of aids and methods of capture among language-groups, which were correlated with the area occupied by these groups. Hunters in delta villages were responsible for almost all of the captures of small juveniles. If juveniles were present in the riverine or coastal areas we would expect fishermen to capture them incidentally, using fishing lines or nets, as often as do fishermen from the delta villages, which was not the case. The delta environment is probably an important nursery and feeding ground for pig-nosed turtles, sustaining the regional populations, as it provides abundant in-stream and allochthonous sources of plants and invertebrates for the diet of juveniles and adults (Georges et al., 2008a,b).

Of the turtles harvested during 2007-2009 $>70 \%$ were females, probably because of the intersection of their dispersal patterns (migration for nesting) with harvest practices (capture while nesting). This could indicate selective harvest of a particular age group and sex, which is supported by the fact that $90 \%$ of the females were captured during trips specifically targeted at harvesting turtles, compared with $50 \%$ of males and no juveniles. Selective harvest could alter genetic attributes and the evolutionary potential of the Kikori pig-nosed turtles by reducing the effective population size and altering behaviour, life history and demography over a short ecological time-scale (Close \& Seigel, 1997; Fordham et al., 2007). This should to be taken into account in the management of this species.

In West Papua (Indonesia) $>70 \%$ of hunting is performed using bow and arrow and trapping, because of the high cost of firearms and cartridges (Pangau-Adam et al., 2012). Similarly, the cost of fuel is the limiting factor for the use of outboard motors in hunting in Kikori but they may become more widely used in the future as a result of increased affluence and engagement in a cash economy. Whether such changes will also involve reduced reliance on subsistence activities, such as hunting, is as yet unknown.

\section{Temporal patterns in harvest}

Introduction of new technology can increase pressure on wildlife and alter the balance between local consumption and trade (Milner-Gulland \& Bennett, 2003). In the Northern Territory of Australia traditional methods of capture of pig-nosed turtles have been displaced by modern fishing technologies (Cann, 1972). Prior to our study no data were available to support anecdotal reports of an increase in the use of new technologies to capture turtles in Kikori (Rose et al., 1982; Georges, 1987; Georges et al., 2006, 2008a).

There was a $30 \%$ increase in the number of turtles captured by fishing line from 1980-1982 to 2007-2009, which may be attributable to an increase in the use of fishing line with the specific objective of capturing turtles. The use of fishing line overall may have also increased but data on the use of fishing line for other purposes in this area are needed to confirm this. The emergence of new hunting technologies is also clear and the use of fishing lines, nets and masks has probably led to an increase in the harvest of juvenile and male turtles, as these are rarely harvested using traditional methods.

The absence of a shift from local-level subsistence hunting towards more intensive commercial hunting is typical of Papua New Guinea, where harvested animals are mainly consumed locally (Mack \& West, 2005; Cuthbert, 2010). However, the Rumu and Kerewo tribes exhibit different temporal patterns in harvesting. There has been a significant increase in the number and proportion of pignosed turtles captured and consumed locally by Kerewo, whereas comparatively fewer turtles were captured by Rumu during 2007-2009, with no significant changes in the proportion of turtles sold in the markets. A lack of alternative economic opportunities is usually a driving force for commercial hunting (Pangau-Adam et al., 2012); however, Rumu villages are situated closer to petroleum enterprises and have higher rates of employment. The improvement of local economic conditions has the potential to decrease hunting frequency (Wilkie \& Godoy, 2001; Milner-Gulland \& Bennett, 2003; Scheffers et al., 2012). 


\section{Conservation and management}

In slow growing, late maturing, long-lived species harvesting of adults has the greatest influence on population decline (Iverson, 1991; Congdon et al., 1993), and moderating the harvest of adult females during nesting should be a priority for management. In the Kikori region the high rate of egg harvest (approaching 97\%; Rose et al., 1982; Pauza, 2003; Eisemberg et al., 2011) is another cause for concern. The removal of eggs reduces recruitment and is linked to many turtle population declines (Martínez et al., 2007; Tomillo et al., 2008). Protecting nesting beaches is an important factor in the recovery of declining chelonian populations elsewhere (García et al., 2003; Dutton et al., 2005; Engeman et al., 2005) and should be considered by the Kikori community to stem or reverse the decline in pig-nosed turtles.

In areas such as Kikori, where hunting products are consumed mostly by the local community, conservation actions are most effective at the local scale (Bennett et al., 2002; Sodhi et al., 2011b; Scheffers et al., 2012). This approach should be bottom-up, with the aim of minimizing the negative effects of hunting (Sodhi et al., 2011a,b). Educational programmes that raise awareness about the decline of pignosed turtles (Eisemberg et al., 2008) may be successful in reducing harvesting (Riley, 2002; Bawa et al., 2004; Scheffers et al., 2012). Providing alternative employment opportunities and sources of protein could also potentially decrease the harvesting of turtles (Musters et al., 2000; Fa et al., 2003; Pangau-Adam et al., 2012).

More information about the life history and population attributes of pig-nosed turtles is needed (e.g. age at first maturity, juvenile recruitment, population size) before local communities can set limits for sustainable harvesting (Rose et al., 1982). Research on these areas should be a priority in Kikori, together with monitoring of nests, the adult population and harvesting. Monitoring is important to assess the sustainability of traditional hunting for long-lived species and has been demonstrated to be crucial in the management of marine turtles, dugongs and crocodiles (Ross, 1997; Kennett et al., 2004; Marsh et al., 2004).

We recommend the establishment of protected areas of beach and feeding grounds, creating employment opportunities for landholders to manage and protect pig-nosed turtles and associated biological assets, and offsetting the financial loss from reduced harvest. Sandbank protection would guarantee the safety of nesting females, which accounted for $48 \%$ of all harvest events we recorded. Measures to moderate trips specifically targeted at harvesting the turtles should be encouraged. Such excursions account for $81 \%$ of the animals captured and $98 \%$ of the females harvested while nesting. All six language-groups in the Kikori region need to be included in this initiative. The lifehistory requirements of the Kikori turtle population draw from resources in all six tribal areas. Furthermore, if any group is excluded from programmes to offset losses from harvesting reductions this will lead to resentment and could result in the resurgence of old land disputes within the region (Warner, 2000). We presented our findings and recommendations to the Kikori communities in 2009, and this led to the creation of the Piku Project. This is an ongoing community-based programme that protects major nesting areas of the pig-nosed turtle and is gathering essential information on the species' demography and life history. Since 2009 the Piku Project has been promoting a long-term community-led turtle monitoring programme and the protection of important nesting sites for pig-nosed turtles in the Kikori delta. Environmental educational materials have also been developed for local schools to raise awareness of the conservation and management of wildlife.

\section{Acknowledgements}

We thank the many people who assisted us in the field, especially our translators M. Boru and B. Oni and our volunteer field assistants L. Bauer, R.F. Silva and S. Reynolds for their exceptional efforts and companionship. We are grateful to all the communities we visited for sharing their knowledge with us. J. Kaiwari, M. Wa'abiya, S. Dekene, A. Nema, A. Moi, R. Kiapranis, M. Veao, S. Ekali, K. Webb (Oil Search Ltd), L. Kaia, D. Badi, F. Kinginapi (WWF) C. Alex and V. Kenisi (Community Development Initiative-Kikori/PNG), and J. Robins (National Research Institute PNG) assisted with logistics. The Papua New Guinea Department of Environment and Conservation and L. Hill of the University of Papua New Guinea assisted us in gaining permission to undertake this research. This project was funded by Oil Search Ltd, with in-kind support provided by WWF.

\section{References}

ACIL-TASMAN (2009) Economic Impact Study-An Assessment of the Direct and Indirect Impacts of the Proposed PNG LNG Project on the Economy of Papua New Guinea. ACIL Tasman Pty Ltd., Hobart, Australia.

Asian Turtle Trade Working Group (2000) Carettochelys insculpta. In IUCN Red List of Threatened Species v. 2013.2. Http://www.iucnredlist.org [accessed 19 May 2014].

BARNES, R.F. (2002) The bushmeat boom and bust in West and Central Africa. Oryx, 36, 236-242.

Bawa, K.S., Kress, W.J., Nadkarni, N.M. \& Lele, S. (2004) Beyond paradise-meeting the challenges in tropical biology in the 21st century. Biotropica, 36, 437-446.

Bennett, E.L., Milner-Gulland, E.J., Bakarr, M., Eves, H.E., Robinson, J.G. \& WilKie, D.S. (2002) Hunting the world's wildlife to extinction. Oryx, 36, 328-329.

Bennett, E.L. \& Robinson, J.G. (2000) Hunting of Wildlife in Tropical Forests: Implications for Biodiversity and Forest Peoples. 
The World Bank, Washington, DC, USA. Http://documents. worldbank.org/curated/en/200o/09/1003157/hunting-wildlifetropical-forests-implications-biodiversity-forest-peoples [accessed 11 May 2014].

Blundell, D. (2006) Digital Language Atlas of the Pacific Area, 6th edition. Http://www.ecai.org/austronesiaweb/PacificMaps.htm [accessed 23 August 2010].

CAMpвELL, L.M. (2002) Science and sustainable use: views of marine turtle conservation experts. Ecological Applications, 12, 1229-1246.

CANN, J. (1972) Notes on some tortoises collected in northern Australia. Victorian Naturalist, 89, 165-168.

Carlton, J.T., Geller, J.B., Reaka-Kudla, M.L. \& Norse, E.A. (1999) Historical extinctions in the sea. Annual Review of Ecology and Systematics, 30, 515-538.

Close, L.M. \& Seigel, R.A. (1997) Differences in body size among populations of red-eared sliders (Trachemys scripta elegans) subjected to different levels of harvesting. Chelonian Conservation and Biology, 2, 563-566.

Congdon, J.D., Dunham, A.E. \& van Loben Sels, R.C. (1993) Delayed sexual maturity and demographics of Blanding's turtles (Emydoidea blandingii): implications for conservation and management of long-lived organisms. Conservation Biology, 7, $826-833$.

Cuthbert, R. (2010) Sustainability of hunting, population densities, intrinsic rates of increase and conservation of Papua New Guinean mammals: a quantitative review. Biological Conservation, 143, 1850-1859.

DAVID, B. (2008) Rethinking cultural chronologies and past landscape engagement in the Kopi region, Gulf Province, Papua New Guinea. The Holocene, 18, 463-479.

Dutton, D.L., Dutton, P.H., Chaloupka, M. \& Boulon, R.H. (2005) Increase of a Caribbean leatherback turtle Dermochelys coriacea nesting population linked to long-term nest protection. Biological Conservation, 126, 186-194.

Eisemberg, C.C., Perini, F.A. \& Georges, A. (2008) The Adventures of Piggy on the Kikori River. Institute for Applied Ecology, University of Canberra, Australia.

Eisemberg, C.C., Rose, M., Yaru, B. \& Georges, A. (2011) Demonstrating decline of an iconic species under sustained indigenous harvest-the pig-nosed turtle (Carettochelys insculpta) in Papua New Guinea. Biological Conservation, 144, 2282-2288.

Enesar Consulting (2005) Environmental Impact Statement. PNG Gas Project. Report CR 790_20_Rev4, Esso Highlands, Port Moresby, Papua New Guinea.

Engeman, R.M., Martin, R.E., Smith, H.T., Woolard, J., Crady, C.K., Shwiff, S.A. et al. (2005) Dramatic reduction in predation on marine turtle nests through improved predator monitoring and management. Oryx, 39, 318-326.

Fa, J.E., Currie, D. \& Meeuwig, J. (2003) Bushmeat and food security in the Congo Basin: linkages between wildlife and people's future. Environmental Conservation, 30, 71-78.

Foley, W.A. (1986) The Papuan Languages of New Guinea. Cambridge University Press, Cambridge, UK.

Fordham, D.A., Georges, A. \& Brook, B.W. (2007) Demographic response of snake-necked turtles correlates with indigenous harvest and feral pig predation in tropical northern Australia. Journal of Animal Ecology, 76, 1231-1243.

García, A., Ceballos, G. \& Adaya, R. (2003) Intensive beach management as an improved sea turtle conservation strategy in Mexico. Biological Conservation, 111, 253-261.

Georges, A. (1987) The pig-nosed turtle, Warradjan. Australian Natural History, 22, 230-234.

Georges, A., Alacs, E., Pauza, M., Kinginapi, F., Ona, A. \& Eisemberg, C. (2008a) Freshwater turtles of the Kikori
Drainage, Papua New Guinea, with special reference to the pig-nosed turtle, Carettochelys insculpta. Wildlife Research, 35, 700-711.

Georges, A., Doody, S., Eisemberg, C., Alacs, E. \& Rose, M. (2008b) Carettochelys insculpta Ramsay 1886-pig-nosed turtle, Fly River turtle. Chelonian Research Monographs, 5, 9.1-9.17.

Georges, A., Guarino, F. \& Bito, B. (2006) Freshwater turtles of the TransFly region of Papua New Guinea: notes on diversity, distribution, reproduction, harvest and trade. Wildlife Research, $33,373-384$.

Gilberthorpe, E. (2009) Development and Industry: A Papua New Guinea Case Study. The Centre for Social Anthropology and Computing, University of Kent, Canterbury, UK.

Gordon, R.G. \& Grimes, B.F. (2005) Ethnologue: Languages of the World. SIL International, Dallas, USA.

Henderson, D.S. (1974) Were they the last Arabian oryx? Oryx, $12,347-350$.

Honegger, R. (1981) List of amphibians and reptiles either known or thought to have become extinct since 1600 . Biological Conservation, $19,141-158$.

Iverson, J.B. (1991) Patterns of survivorship in turtles (order Testudines). Canadian Journal of Zoology, 69, 385-391.

Kennett, R., Robinson, C.J., Kiessling, I., Yunupingu, D., Munungurritj \& Yunupingu, D. (2004) Indigenous initiatives for co-management of miyapunu/sea turtle. Ecological Management \& Restoration, 5, 159-166.

LynCH, O. \& MARAT, A. (1993) A review and analysis of national laws and policies concerning customary owners' rights and the conservation and sustainable development of forests and other biological resources. In Papua New Guinea Conservation Needs Assessment Report (eds B.M.P. Beehler \& J.F. Swartzendruber), pp. 7-29. The Biodiversity Support Program, Washington, DC, USA.

MACK, A. L. \& WeSt, P. (2005) Ten thousand tonnes of small animals: wildlife consumption in Papua New Guinea, a vital resource in need of management. Resource Management in Asia-Pacific Working Paper No. 61. Resource Management in Asia-Pacific Programme, Research School of Pacific and Asian Studies, Australian National University, Canberra, Australia.

Marsh, H., Lawler, I.R., Kwan, D., Delean, S., Pollock, K. \& Alldredge, M. (2004) Aerial surveys and the potential biological removal technique indicate that the Torres Strait dugong fishery is unsustainable. Animal Conservation, 7, 435-443.

Martínez, L.S., Barragán, A.R., Muñoz, D.G., García, N., Huerta, P. \& Vargas, F. (2007) Conservation and biology of the leatherback turtle in the Mexican Pacific. Chelonian Conservation and Biology, 6, 70-78.

Mascia, M.B., Brosius, J.P., Dobson, T.A., Forbes, B.C., Horowitz, L., McKean, M.A. \& Turner, N.J. (2003) Conservation and the social sciences. Conservation Biology, 17, 649-650.

Milner-Gulland, E.J. \& Bennett, E.L. (2003) Wild meat: the bigger picture. Trends in Ecology \& Evolution, 18, 351-357.

Musters, C.J.M., de Graaf, H.J. \& ter Keurs, W.J. (2000) Can protected areas be expanded in Africa? Science, 287, 1759-1760.

Nasi, R., Brown, D., Wilkie, D., Bennett, E., Tutin, C., Van Tol, G. \& Christophersen, T. (2008) Conservation and Use of Wildlife-based Resources: The Bushmeat Crisis. Secretariat of the Convention on Biological Diversity, Montreal, and Center for International Forestry Research, Bogor, Indonesia.

Nazarea, V., Rhoades, R., Bontoyan, E. \& Flora, G. (1998) Defining indicators which make sense to local people: intra-cultural variation in perceptions of natural resources. Human Organization, $57,159-170$. 
Pangau-Adam, M., Noske, R. \& Muehlenberg, M. (2012) Wildmeat or bushmeat? Subsistence hunting and commercial harvesting in Papua (West New Guinea), Indonesia. Human Ecology, 40, 611-621.

Pauza, M. (2003) The Pig-nosed Turtle Project. Report to WWF, Boroko, Papua New Guinea.

PNG Census (2000) Provincial Report. National Statistical Office of Papua New Guinea, Port Moresby, Papua New Guinea.

Price, J.B., Power, A.P. \& Don, H. (1994) Kikori River Basin Project to Sustain Environment Alongside Development. The Asia Pacific Oil \& Gas Conference, Melbourne, Australia.

Riley, J. (2002) Mammals on the Sangihe and Talaud Islands, Indonesia, and the impact of hunting and habitat loss. Oryx, 36, 288-296.

Rose, M., Parker, F. \& Rhodin, A.G.J. (1982) New Guinea plateless turtle or pitted shell turtle (Fly River or pig-nosed turtle), Carettochelys insculpta Ramsay 1886. In The IUCN Amphibia-Reptilia Red Data Book, Part 1, Testudines, Crocodylia and Rhychocephalia (eds B. Groombridge \& L. Wright), pp. 243-246. IUCN, London, UK.

Ross, P. (1997) Biological basis and application of sustainable use for the conservation of crocodilians. In Memorias de la 4 ta. Reunion Regional del Grupo de Especialistas de Cocodrilos de America Latina y el Caribe, pp. 182-187. Centro Regional de Inovacion Agroindustrial, S.C. Villahermosa, Tabasco, Mexico.

Scheffers, B.R., Corlett, R.T., Diesmos, A. \& Laurance, W.F. (2012) Local demand drives a bushmeat industry in a Philippine forest preserve. Tropical Conservation Science, 5, 133-141.

Sodhi, N.S., Butler, R., Laurance, W.F. \& Gibson, L. (2011a) Conservation successes at micro-, meso- and macroscales. Trends in Ecology \& Evolution, 26, 585-594.

Sodhi, N.S., Butler, R. \& Raven, P.H. (2011b) Bottom-up conservation. Biotropica, 43, 521-523.
Sodhi, N.S., Koh, L.P., Brook, B.W. \& NG, P.K.L. (2004) Southeast Asian biodiversity: an impending disaster. Trends in Ecology \& Evolution, 19, 654-660.

Stuв в, D. (1989) Tortoises and Freshwater Turtles: An Action Plan for Their Conservation. IUCN/SSC Tortoise and Freshwater Turtle Specialist Group, Canterbury, UK.

Tomillo, P.S., Saba, V.S., Piedra, R., Paladino, F.V. \& Spotila, J.R. (2008) Effects of illegal harvest of eggs on the population decline of leatherback turtles in Las Baulas Marine National Park, Costa Rica. Conservation Biology, 22, 1216-1224.

W Arner, M. (2000) Conflict Management in Community-based Natural Resource Projects: Experiences from Fiji and Papua New Guinea. Working Paper 135. Overseas Development Institute, London, UK.

W ILKIE, D.S. \& Godoy, R.A. (2001) Income and price elasticities of bushmeat demand in lowland Amerindian societies. Conservation Biology, 15, 761-769.

W URm, S.A. \& Hattori, S. (1981) Language Atlas of the Pacific Area. Australian Academy of the Humanities and the Japanese Academy, Canberra, Australia.

\section{Biographical sketches}

Carla C. Eisemberg studies the ecology and conservation of freshwater turtles in the tropics. She is interested in community-based environmental education and wildlife management. ARTHUR GEORGES has a broad interest in research that underpins decisions on the management of the natural environment. BENEDICT YARU is interested in environmental management and restoration and has over 17 years of experience in Papua New Guinea. MAR K Rose spent the early part of his career specializing in the sustainable conservation management of wildlife, particularly crocodiles and pig-nosed turtles in Papua New Guinea. 